\title{
3 The Late Middle English Version of Practica Urinarum in London, Wellcome Library, MS 537 (ff. 15r-40v) $^{1}$
}

Javier Calle-Martín

University of Málaga

\section{Introduction to the edition}

Mediaeval uroscopic treatises have been traditionally underestimated in the last decades, to such an extent that they can be safely deemed to be the Cinderella of the subject categories of Medicine, especially if compared with Herbals, Remedybooks and Leechbooks (Keiser I998: 366I; Calle-Martín 20I2: 243). Using Voigts and Kurtz's electronic database of Scientific and Medical Writings in Old and Middle English (2000), Tavormina has found that the subject field 'Urine and Uroscopy' contains 408 texts, representing "the fourth largest in the entire database, preceded only by 'Recipes', 'Alchemy', and 'Herbs and Herbal Medicine'” (Tavormina 2005: 40; 6I). Unfortunately, however, many of these uroscopic treatises are hitherto unedited and, more importantly, they are still waiting for a patient scholar to investigate the textual tradition of the extant witnesses (Tavormina 2009: $\mathrm{S}_{33}-\mathrm{S}_{4} \mathrm{I}$ ). According to Tavormina, there is a scholarly gap in the field and further research is needed in the following three areas: a) the publication of more uroscopic treatises in the vernacular; b) the complete taxonomy of the texts in Middle English; and c) the relations of these texts to their Latin/English sources (2005: 4I).

I The present research has been funded by the Spanish Ministry of Science and Innovation (grant number FFI20I I-26492) and by the Autonomous Government of Andalusia (grant number PII-HUM7597). These grants are hereby gratefully acknowledged. This Festschrift article is dedicated to Prof. Nils-Lennart Johannesson, a keen attender of Selim conferences in Spain (The Spanish Society for Medieval English Language and Literature), on the occasion of his retirement.

How to cite this book chapter:

Calle-Martín, J. 2015. The Late Middle English Version of Practica Urinarum in London, Wellcome Library, MS 537 (ff. I 5 r-4ov). In: Shaw, P., Erman, B., Melchers, G. and Sundkvist, P. (eds) From Clerks to Corpora: essays on the English language yesterday and today. Pp. 35-52. Stockholm: Stockholm University Press. DOI: http://dx.doi. org/Io.I6993/bab.c License: CC-BY. 
Our analysis then falls within Tavormina's first area and contains the semi-diplomatic edition of the Middle English version of Practica Urinarum, a small uroscopic treatise instructing the mediaeval practitioner on the examination of urine in the light of the following three elements: substance, colour and sediment. The text also reports what must be considered for the treatment of the patient, i.e. his/her age, duration of illness, the time of greatest suffering together with "further questions regarding the time of the specimen and the diet of the patient" (Keiser I998: 3662). As far as we have been able to investigate, the text has been preserved (completely or partially) in seven different witnesses (Keiser I998: 3852 ):

- London, Wellcome Library, MS Wellcome 537, ff. I 5r-40v (c. I460).

- Cambridge University Library, Gonville and Caius College, MS $336 / 825$, ff. I32V-I36r (I480-I 500).

- Cambridge University Library, Trinity College, MS O.ı.77, ff. 2 Ir-29V (c. I460).

- British Library, MS Sloane 2320, ff. 4r-9v (c. I458).

- British Library, MS Sloane 3566, ff. 24r-33v (I450-I475).

- Boston Medical Library, MS Countway I9, ff. I4r-I8v (c. I460).

- Yale University Library, Takamiya 33, ff. 24V-37r (I480-I 500).

MS Wellcome 537 has been used as the source text for the present edition, which is hitherto unedited. With the title Miscellanea Medica VII, MS Wellcome 537 is a relatively small volume written in octavo size, measuring approximately I $4.5 \mathrm{x}$ II $\mathrm{cm}$. The volume houses a collection of eight anonymous treatises, both in English and Latin, on medical astrology, weather prediction, uroscopy together with a collection of medical receipts. The following collation relies on Moorat's accurate description of the volume (I962: 394-395):

- [Anon.] Canon pro medicinis dandies (in Latin), ff. 6r-I2r.

- [Anon.] Menses per circulum anni (in Latin), ff. I2v-I4v.

- [Anon.] Seeing of Urines (in English), ff. I 5r-4ov.

- [Anon.] Medical receipts (in English), ff. 40v-46v.

- [Anon.] Practica medicinae (in English), ff. 48r-3 rov.

- [Anon.] Table of Golden Numbers and Dominican Letters, ff. 3 I $5 \mathrm{v}-3$ I $8 \mathrm{v}$.

- [Anon.] De cursu lunae (in Latin), ff. 3 I 8v-325r.

- [Anon.] On the Changes of the Moon (in English), ff. 326r-333r.

Even though the volume had been previously dated by Francis Douce (I757-I 834) to the first half of the I 5 th century, Moorat reports that 
there is an autograph letter to Dr Joseph Frank Payne (I840-I9Io) from Thomas Wright (I8IO-I 877), proposing to date the composition of the volume to the year I 462 because "the whole of it is written in the hand which is common enough throughout the reigns of Henry VI and Edward IV" (Moorat I962: 395). The palaeographic analysis of the scribe's handwriting confirms it to be a hybrid script composed in the second half of the 15 th century in the light of the overwhelming preference for the Secretary script, with just sporadic tinges of the Anglicana (Petti 1977: I 5). Fig. I below reproduces the inventory of letterforms used in MS Wellcome 537 where the letters have been numbered for reference purposes. As shown, the Secretary script is witnessed in the use of distinctive letterforms, which sharply differ from the conventional cursive hand of the Anglicana. Among others, the following stand out: the single-lobed $<\mathrm{a}>$ with a pointed head (I); two-lobed $<\mathrm{b}>(2)$; the letter $<\mathrm{d}>$ with a looped stem $(4)$; the letter $<\mathrm{k}>$ with its characteristic rightarced headstroke (IO); the letter $<\mathrm{l}>$ with a lobed arm (I I) (Clemens and Graham 2007: I67-I68); the right-shouldered $<\mathrm{r}>$, footed and sitting on the script line (I7); the heavy ascender of the letter $\langle\mathrm{v}>(24)$; and the letter $<\mathrm{w}>$ already resembling a double $\mathrm{v}(25)$.

Already in the second half of the 15 th century, "the two competing Gothic cursiva scripts often seem so intermingled as to have produced a new cursive book script, typically Secretary in ductus, but using Anglicana round $e$ and sigma-shaped $s$ as cursive features and liable to adopt other Anglicana letterforms" (Roberts 2005: 2I 2-2 I3; Derolez 2003: I62; also Denholm-Young I954: 28-29; Hector I966: 58). In this fashion, the Anglicana script is limited to the use of the following four distinctive letters in MS Wellcome 537: the round <e> (5);

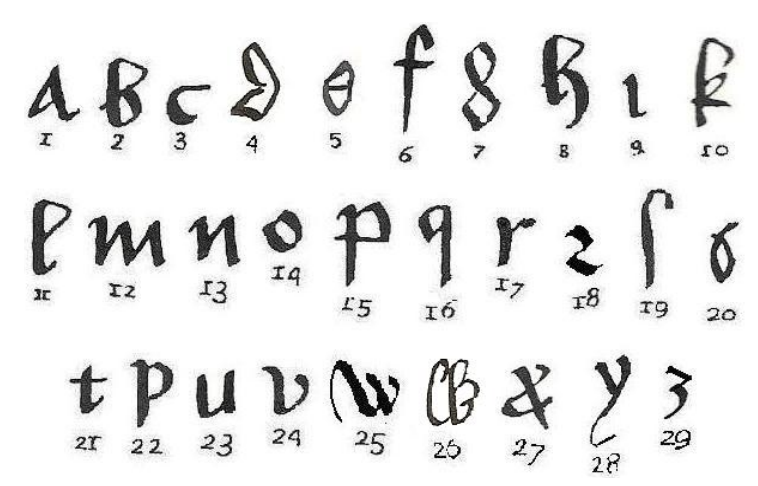

Figure 1. Inventory of letterforms in MS Wellcome 537. 
the two-compartment figure 8 form of $<\mathrm{g}>(7)$; the sigma-like $<\mathrm{s}>(20)$; and the letter $<w>$ consisting of a double $<$ l $>$ together with a 3 (26).

The principles of a semi-diplomatic edition have been adopted in the present edition so as to render an accurate reproduction of the source text, complying with the following guidelines, partially adapted from Clemens and Graham (2007: 75-8I; also Calle-Martín and MirandaGarcía 20I 2: 67-68): a) the spelling, capitalization and punctuation of the original have been retained; b) abbreviations have been expanded with the supplied letter(s) italicized; ${ }^{2}$ c) insertions, both of single letters and words, have been inserted in their proper sequence in the body of the text; ${ }^{3} \mathrm{~d}$ ) word separation has been normalized, regardless of whether words are run together without separation or whether a gap is left within a word; and e) lineation and paragraphing have been disregarded for reasons of space.

\section{The Middle English text ${ }^{4}$}

$\{$ f. I 5 r $\}$. ihc .

II here begynnep pe practise of the sighte of vrynes . HIt is to vndurstonde pat who so wille loke an vryn : him behouep to considere pre pinges / Firste he muste aske pe age of pe pacient or seke body . and how longe his sekenes hap holde him . and what tyme hit toke him furste and whiche tyme of pe day or of pe nyzt hit greuep him moste . Also if pe vryn were made and brouzte in a clene vessel and bat hit were pe furste water after mydnyz Also pe dyete of pe seke body $\{$ f. I $5 \mathrm{v}\}$ wheper he hap vsed highe metis and drinkes : or ellis lowe. Also hit behouep to consider pe substaunce of pe vryn wheper hit be picke or bynne and pe qualite wheper it be highe or lowe of coloure. and pe quantite wheper it be litil or moche . and pe contentis . and pe cloudes pat be $n$ peryn. And in whiche regiou $n$ pey be $n$ yn: and if pey be oueral in liche colourid . or if hit be more remise in oon regioun: pan in anoper . or if hit be of twoo colouris : or if hit be oueral in liche colourrid . bope intencioun and remissioun . \{f. I $6 \mathrm{r}\}$ Than hit behouep principally to wyten by consideracioun of pe vryne and by askyng also what be maledy is . wheper hit be a feuer or anoper maledy. and wheper hit be

\footnotetext{
2 Superior letters are lowered to the line, as in $\mathrm{w}^{\mathrm{t}}>\mathrm{w}$ ith or $\mathrm{p}^{\mathrm{e}}>$ pe. Superfluous brevigraphs and otiose flourishes, in turn, have been disregarded.

3 Insertions above the line and in the margin have been noted with the use of slashes (/ $)$ and double slashes (// I), respectively.

4 (c) Wellcome Library (London) as the owner of the manuscript.
} 
in pe begynnyng . or ellis in state . or in pe ending. Also when pu hast vndirstonde . al bis . and pe vryne of pe pacient . is brouzte to pe : pu muste considere pre pingis in euery vryn . pat is to sey . pe substaunce . pe coloure and be sedymen. Oon is cause of colour. anoper is cause of substaunce . pe pirde is cause of sedymen. Now in euery man is body is foure qualitees . hete and colde . moyste $\{\mathrm{f} . \mathrm{I} 6 \mathrm{v}\}$ and drye $:$ hete and colde : pey ben causers of colours. Drynes and moystenes : pey ben cause of substaunce. /hetel is cause of rede coloure. drynes is cause of byn substaunce . moystenes is cause of pycke substaunce. As pus . if pe vryn of pe pacient be rede and picke : it signifiep pat blode hap more dominacioun ban an oper. Why : For blode is hote and moyste . If it be rede and bynne : hit shewep pat colere hap dominacioun. For why . colere is hote and drye. If pe vryn appere white and picke : hit betokenep fleume . For fleume is colde and \{f. I $7 \mathrm{r}\}$ moyste . If pe vryn shewe white and bynne $:$ it sygnifiep malencoly. For malencoly is colde and drye. When pu hast considerid wel as pis : ben beholde pe diuersite of colours of pe vryns and pe cercles of hem. whiche now folowen .

Karapos . is an vryn in coloure : like to kamellis flesshe . whiche is a colour white douny . and in substaunce hit is byn. The whiche swewep ${ }^{5}$ and signifieb pe droppesy . or a wynde vndur pe syde . pe stone . pe hede ache . a posteme in pe longis . or a $\{\mathrm{f} . \mathrm{I} 7 \mathrm{v}\}$ or elles a fleume. II Plumbea : is an vryn in colour lyke to lede . whiche signifiep be falling yuel . or membris broken . or a palsy . or a feuer tertian . or difficulte of water making . or womman is floures II Pallida : is an vryn /in colour like to flesshe halfe soden be iuse not putte oute . which signifiep a feble hede . or a feuer. or a colde stomake. or a brennyng vndur pe lyuer . or wastyng of longes. II Plumbea : is an vryn in coloure $\{\mathrm{f}$. I $8 \mathrm{r}\}$ like to lede . as hit writen tofore of colour pallida II Viridis : is an vry $n$ bat is grene in colour like to be caule leaf . whiche betokenep wasting of kynde/li\ hete . pe morfu . or be hede ache . or pe iaundyse . or chasing of pe luyer and wasting of kyndeli hete. II Inopos $:$ is an vry $n$ in colour like to a man is lyuer . or to olde rede wyne yturned into blackenes . whiche betokenep pat pe galle brennep pe lyuer . and perof commep pe iaundise. or hit signifiep a veyne roten /or broken $\backslash$ of the /rleynes . or to myche delynge wip a womman . \{f. I $8 \mathrm{v}\}$ II Subpalida $:$ is an vryn in coloure /likel to iuse of flesshe halfe soden . and be iuse yputte oute. The whiche betokenep a posteme in pe rizt syde. or a tysike . or hardenes to make water II

5 Probably an erroneous form for $<$ shewep $>$. The $e-M E D$ notes a similar form (ie. swewe) which is identified as an error. 
Rubicunda : is an vryn in colour like to a flaume of fyre sentte oute . The whiche betokenep a feuer acute and sharpe . and vndursette at pe herte . defaute of wynde and a drie coughe. II Subcitrina $:$ is an vry $n$ in colour. like to be iuse of an appel orynge . whiche betokenep a feuer agu . and pe same as dope cytryne \{f. I9r\} coloure but not so myche . ne so perfite. II Subrufa $:$ is an vryn in colour like to golde and siluer medelid togedir . whiche betokeneb a feuer tertian . or a posteme vndur pe ribbes . or pe goute . or a tisike . /or l shortenes of wynde . and simple bitternes in taste and grete dryness $\mathbb{T I}$ Subricunda : is an vry $n$ in colour like to a flaume of fyre not sente oute. This betokenep as dope subrufa . but pat pe yuel is more greuous in pis : pan hit is in pat other. $\{\mathrm{f} . \mathrm{Igv}\}$ II Rubea : Rede vryn is in coloure like to safron in dorte . whiche betokenep a feuer poroughe chafyng of pe lyuer . or a feuer quarteyn . or ellis a posteme of pe longis . begynnyng of a dropesy . or of a morfu . If Citrina : is an vry $n$ like to pe coloure of an appelle of an orynge . whiche betokenep wasting of pe splene and of pe lyuer . commyng of pe frenesy . and hete aslaked in a feuer tercian. II Subrubea : is an vry $n$ in colour like to safron belynge . whi\{f. 2or\}che betokenep a feuer of corrupte blode /in pe veynes $\backslash$. or a veyne broken in pe backe. or ellis pe floures of wommen. II Rufa : is an vryn in colour like to pured golde. The whiche betokenep pe emoyraudis . or pe dropesy . or passing of floures - Il kaynos $:$ is an vryn in colour like to blacke wyne or to blacke water . And hit betokenep a crampe in pe veyne of pe herte . or a posteme in pe stomake . or ellis pe goute.

II Lactea $:$ is an vry $n$ in coloure $\left\{\mathrm{f}_{\mathrm{g}} 2 \mathrm{ov}\right\}$ like to whey of coughe mylke and hit betokenep depe if pe paciente slepe not . or ellis a frenesy . or a longe /during\feuer. II Subuiridis : is an vryn in colour clere as pe welle water. And hit betokenep pe same as dope pe rede coloure. but not so perfitly. II Alba : is an vryn in colour as clere welle water. and hit betokenep wasting of pe splene . or pe dropesy . or pe stone and greuaunce in pissyng . or pissing ageyne wille . or pe emoyraudis . or stopping of floures . cha\{f. 2 Ir\}fyng of pe lyuer . wodenes . and in axces and feuer : hit is depe. II Nigra $:$ is an vry $n$ in colour like to blacke ynke or to a brent horne. And hit betokenep a feuer quarteyn . or a blacke iaundise . peryl of depe in shorte tyme. II Glauca : is an vryn like in colour to a shenyng horne. And hit betokenep a posteme in pe rizt side . or a feuer etike . or /al bladder on the longis .

II Her endep pe significacioun of /pe coloures $\backslash$ of vryns Now we wille $\{$ f. 2 Iv $\}$ declare and telle of pe Cercles of vryns and begynne at pe hede of man A Cercle pat is grete shevweb pe feblenes of pe hede and moche 
akynge peryn. II A . cercle pat is white and pycke . signifiep pat fleume hap duracioun in be hynder parte of pe hede . for bat is his resting place . II A . cercle white and clere . signifiep pat malencoly hap duracioun on pe lifte syde of pe hede . for pat is his sete. II A . cercle pat is rede and picke . signifiep pat blode hap duracioun in pe forehede. for pat is his sete. II A . cercle rede and clere : signifiep bat colere hap duracioun . $\{\mathrm{f} .22 \mathrm{r}\}$ in pe rizte side of pe hede . for bat is his restyng place. II If a cercle shewe or appere grene $:$ hit betokenep grete ache in pe hede and vnder pe rizte side. II If a cercle appere white : hit signifiep grete ache in be hynder party of be hede. II If a cercle appere rede : hit betokeneb ache in pe forehede. And if hit appere blacke : hit signifiep be falling yuelle. II If per be in a cercle smale bollis as pey were of reyne water: hit betokenep a wynde in be $\{$ f. $22 \mathrm{v}\}$ hede . risyng oute of pe stomake . II If per be in a cercle mottis as be $n$ in be sunne : hit betokenep a reume of pe hede . or pe pose . or deffenes . or heuynes. II If per appere in a cercle a tree $:$ hit betokenep a posteme in be bladder. or ellis in pe lyuer. II If per appere in a cercle fattenes : hit signifiep a feuer . or ellis streittenes at/pel breste. II If blode appere in a cercle $:$ hit betokenep breking of a veyne in be backe. If pe /vryn lappere blac\{f. 23 r\}ke : hit betokenep depe . which is causid of be blacke iaundise. or ellis of pe feuere quarteyn. II Water ful of smale predis : betokenep dry complexiou $n$. or ellis a posteme in pe rizte side. II White grauel appering in a cercle signifiep pe stone in be bladder. Rede grauel : betokenep ache in pe reynes . and also a spice of pe stone. Blacke grauel betokenep ache in pe rigge bitwene pe kidneys. Shales as hit were of fysshes betokenep stopping of floures . and a scabbe in pe matrice .

II here endip pe cercles $\{\mathrm{f} .23 \mathrm{v}\}$ of vryns with her significacions and now folowep be contentes of hem . and pe passing excesse of hem . and be oper declaryng of which ben gode and holsum and commendable. Eche vryn is clensing of blode . as hit is propurly proued of two pinges significatife . or forsope hit signifiep of pe lyuer and of pe veynes . or of pe bladder and of pe reynes. Of oper pinges hit is yppirliche significatyfe . II But in vryn lokep and beholdep diuerse pinges . pat is to wite . substaunce . coloures . regions . and pe contentes. Anoper is because $\{\mathrm{f} .24 \mathrm{r}\}$ of substaunce. Anoper is because of coloure. Anoper is becau $^{6}$ of residens. Now in euery man is body is foure qualitees . hete and colde . moystenes and drynes. hete and colde : pey ben cause of

${ }^{6}$ An erroneous form instead of < because $>$. The scribe does not provide the full form of this conjunction probably because the word is broken at the end of the line. 
coloures . Drynes and moystenes : pey ben cause of substaunce. As pus hete is cause of rede coloure . Colde $:$ is cause of white coloure. Drines $\because$ is cause of pyn substaunce . moystenes $!$ is cause of picke substaunce . II An vryn is deuided in foure parties . pe one party : is be cer $\{\mathrm{f} .24 \mathrm{v}\}$ cle . pe secunde $:$ is pe body of pe eyre . pe pridde $:$ is perforaciou $n$. pe fourpe $:$ is pe grounde. II By pe cercle $:$ is seen pe sekenes of pe hede and of be brayne. By be body: alle yuelis and sekenes of pe spirituel membris and of pe stomake. By perforacioun: sekenes of pe lyuer and of pe splene. By pe grounde: we shewen accidentes of pe reynes and of pe matrice . and of pe priue membris / II An vryn hap pre regions . pat is . pe nepereste bygynnep fro pe grounde of pe vrynal and durep \{f. $25 \mathrm{r}$ \} by pe space of two fyngers / pe myddel regioun begynnep ber as pe neper endep : and durep to pe cercle . pe whiche cercle is pe ouermeste regioun. And when ber is in be ouermeste regioun as fome : hit signifiep ventosite bulnyng vppe in pe veynes of pe vryn . or ellis inflacioun . or oper vices or sekenes of pe lungis. II If /so be pat $\backslash$ pe cercle be picke : hit signifiep to moche repleciou $n$ in be hede and doloure or ache . A . white cloude appering in be myddel regiou $n$ : in hole men is an yuel signe . but in men bat haue be feue\{f. $25 \mathrm{v}\}$ res . hit signifieb digestioun of pe mater and of pe yuel. In pe nepermeste regioun if per appere grauel or litil stones . hit shewep /pat pe paciente is ful of litil stones . and is greued with pe vice of pe stone. Operwhile pe residence is blacke $\mathrm{\text {if }}$ bat falle in a feuer quarteyn . or for kyndely hete yquenchid $:$ hit is a signe of depe. If it be for expulsioun of venomous mater whiche is putte oute by pe vry $n:$ hit is a toke $n$ of helpe / II If an vryn be white at morwe and brovne after mete : hit $\{\mathrm{f} .26 \mathrm{r}\}$ signifiep gode helpe and welle. II If an vryn be fatte and trobely : hit betokenep water in pe bowwelis / II If an $\operatorname{vry} n$ be rizt rede and clere . hit signifiep a brennyng feuer / II If an vry $n$ be oueral rede and picke with a blacke cercle $:$ hit signifiep grete sekenes and feruent . and but if he swete : hit is depe / II If an vryn be white and bynne and a litil dymmy : hit signifiep a coldenes in pe body. If If an vry $n$ be dymme and sumdel rede . with a blacke cercle : /it $\backslash$ signi\{f. 26v\}fiep a badde stomake . do medisyn. II If an vry $n$ be clere and hap a blacke cercle : hit is depe. II If an vry $n$ be bynne . and grene abouen : hit signifiep a colde complexioun . and if in pe casting be blode abouen $\because$ it is a tisike. II If an vry $n$ be dymme and blacke abouen . or vndir be cercle in pe casting : hit betokenep luste of kynde . and he wolde haue a woman to pley / II If an vryn be picke and trobely like horse pisse . hit signifiep grete hede ache . do to him medisyne. \{f. $27 \mathrm{r}\}$ II If an vryn be fatte in be bottym . and white in pe myddes . and rede abouen . hit 
is a feuer quarteyn. II If an vryn appere flessheli and haue drestis in pe bottum as shauyng : hit is a dropesy. Also if hit be as whey aboue . and clere in pe myddis . and shadwep benepe $:$ hit is pe colde dropesy . II If an vry $n$ haue drestes in be bottum like gobettis of coles and ben departid asounder and not to grete : hit signifiep a worme in pe body . do medisine / II If an vryn haue blacke contentes and smale as mottes stonding in $\{\mathrm{f} .27 \mathrm{v}\}$ pe myddes of pe water. hit signifiep a posteme in pe side. II If an vry $n$ haue in be bottum like gobettis of flesshe of smale shawyng : pat is a token of stopping of pe reynes and also of pe pipis of pe lyuer . do to him medisine II If an vryn /bel blacke and grene with longe contentes like to be sparme of man . hit is pe palsy . and hit be frotthi and like lede in pe myddes : it is pe same / II If an vryn haue greynes vndir be sides of pe cercle : hit signifiep a stomake ful of \{f. $28 \mathrm{r}\}$ humours . and brennyng at pe breste . do to him medisyne. II If an $\operatorname{vry} n$ haue askes aboue $:$ hit /is $\backslash$ harme in alle pe spiritual parties of al be body . do medisine / II If an vryn haue contentes white and blacke in be bottum : hit is costifnes / II If an vryn abide longe lefting pinne : hit signifiep swelling in pe body . and moche reume and humours peryn . II If an vryn be pycke and litil in quantite : hit is token of pe stone / II If an vryn be fropthi and clere and litil in quantite and also rede : $\{$ f. $28 \mathrm{v}\}$ hit signifiep peyne in pe rizt side ./ II If an vry $n$ haue grete frope after pe casting . hit signifiep wynde in be bowel/lis and peyne vndir be sides and bad stomake / II If an vry $n$ be rede as brenning golde $:$ hit is pe $\mathrm{d} r o p e s i$ of depe / II If an vry $n$ be as brennyng cole : hit is a posteme on pe lyuer. do to him medisyne.

URyn as flaume of fyre sente oute / Vryn as safron belynge / Vry $n$ as safron dorte / Vryn as flavme of fyre not sente oute / These foure signifien excesse of digestion / \{f. 29r\} II Vryn of pe coloure of a man is lyuer / Vryn of pe coloure of blacke water / Vryn pat is grene as a caule lefe / These thre . signifien moche adustioun and brennynge. II Vryn pat is pale of colour as is lede / Vryn bat is blacke in colour of adustion . as is ynke / Vry $n$ pat is blacke in colour as blacke water. or as a blacke horne / These pre : betoken mortificacioun land sleinge / II Vryn pat is clere as welle water / Vryn pat is shenyng as a horne / \{f. 29v\} II Vryn in colour as whey of mylke / Vryn pat is white douny as is pe flesshe of a camel / These foure signifien indigestioun / II Vryn like to iuse of flesshe halfe soden . pe iuse yput oute / Vryn like to flesshe soden pe iuse not yputte oute / These ij $^{\circ}$ signifien pe begynnyng of digestioun / II Vryn bat is as pe colour of pe iuse of an orynge appel / Vry $n$ bat is like to be appel of orynge /rindel / These ij ${ }^{\circ}$ signifien myddel digestioun / \{f. zor \} II Vryn 
pat is as golde and siluer meddelid togeder / Vryn bat is as golde purid - pese ij $^{\circ}$ signifien parfite digestiou $n$ / And bis vryn rufa : betokeneb helpe and gode disposicioun of man is body / Vryn subrufa signifiep gode helpe : but not so perfitely in ony maner as dope rufa . II Vryn pat is of pe colour of an orynge appel. Whan hit is white and a myddel substaunce . and when pe cercle is of pe same coloure $:$ hit is praisable / Vryn pat is of colour as is pe iuse of an appel orynge : is not so \{f. $30 v\}$ perfite as is colour citrine : for citrine is best colour / II Vryn bat is of coloure as is pe rede rose betokenep a feuer : pat is callid effimera . and if a man pisshe contynuelly : hit signifieb a feuer contynuel. II Vryn pat is of colour as blode in a glasse : betokeneb a feuer of to moche blode . and pan anoon a man muste be letid blode . but if be mone be in pe signe of geminorum . II Vryn pat is grene as is pe caule lefe when hit is pissid: and afterwarde apperep rede: $\{\mathrm{f}$. 3 Ir $\}$ hit betokenep adustioun and sore barnyng . and hit is mortal and depe / II Vryn pat is rede in al maner . remeued fro cleernes : betokenep declynyng of be yuel . and amendyng of pe sekenes. II Vryn pat is rede meddelid sumwhat with blackenes : betokenep pe yuel of pe lyuer . and of pe herte. II Vryn pat is pale as flesshe halfe soden : betokenep defeccioun or feblenes of pe stomake . and letting of pe secounde digestioun. II Vryn pat is white as is welle \{f. $3 \mathrm{IV}\}$ water in hole men: hit betokenep rawenes of humours . and in sharpe feuers $:$ hit is depe / II Vryn in colour as whey of mylke with picke substaunce . if hit falle in a womman : hit is not so perilouse as hit is in a man / for pe inordenaunce of pe matrice . but neuer be late in sharpe feueres : hit is depe / II Vryn in coloure aboue : as whey of mylke . and bynepe shaduep abouten pe myddel regioun clere . hit betokenep be dropesy / Also if pe vryn of him \{f. $32 \mathrm{r}\}$ bat hap pe dropesy be rufa . or subrufa . hit betokenep depe / II Vryn pat is white douny . as is camelle flesshe : betokenep multitude of corrupte humours . which befallep in fleumatikes . ydropekes . podagres . and so of oper. II Vryn pat is blacke : may be of kyndely hete yquenchid . and pan hit is mortale and depe / Or hit may be for expulsioun of venomous mater. whiche is putte oute by pe vryn . and pan hit betokenep helpe . In a feuer quartey $n$ : hit is euermore depe / $\{\mathrm{f} .32 \mathrm{v}\}$ II Vryn in colour as /al shenyng horne betokenep yuel disposicioun of pe splene . and disposicion of pe feuer quarteyn / I Vryn in colour as safron in dorte with picke substaunce . and stinkyng and fomy . betokenep pe iaundise. II Vryn in colour as purid golde . and vryn as golde and siluer meddelid togedir . hauyng bynepe rounde resolucioun and white aboue : and sumwhat fatty . betokenep pe feuer etike . II Vryn in pe grounde of pe vessel vnto pe myddil clere $\{\mathrm{f} .33 \mathrm{r}\}$ 
after picke and bynne betokenep harme in pe breest II Vryn pat is fomy and clere : and in colour as safron belinge : betokenep more harme in pe rizt syde : pen in pe lifte side / II Vryn if hit be white and fomep : hit betokenep more harme in pe lifte side $:$ pen in pe rizt side. for pe lifte side is more colde ben pe rizte side. II Vryn pat is pinne and pale and also cleer : betokenep acetosum fleuma / If pe cercle of pe vryn be not resting but tremblyng : hit betokenep rennyng of fleume $\{\mathrm{f} .33 \mathrm{v}\}$ and of oper humoures fro pe hede . by pe necke to neper parties / II Vryn picke and mylky and litil in quantite and fatte bynepe with shalis : betokenep pe stone / and if be vryn be withoute shalis and be picke and mylky and litil in quantite : hit signifiep pe fluxe in pe wombe / Vryn picke and mylky and hap meny dropes in pe ouer parties : signifiep pe goute in membris of pe body. II Vryn pat is pale binepe in men : betokenep harme in be reynes Vrin in whiche litil gobettis apperen . if hit be litil and trobelid $\{\mathrm{f} .34 \mathrm{r}\}$ hit signifiep brennyng of a veyne aboute pe reynes in pe bladder / II Vryn in whiche quitoure apperep in pe grounde of pe vessel : betokenep roting of be bladder . or ellis a posteme / And if per appere quitoure poroughe alle pe vry $n$ : hit betokenep roting of al pe body / Vryn in whiche frustis apperen litil and brode : hit signifiep excoriacioun of be bladder / Vryn motty : signifiep by longe tyme pe stone in pe reynes / II Vryn pat is white wipouten feuer bope in man and womman oper\{f. $34 \mathrm{v}$ \}while hit signifiep harme in pe reynes . and operwhile in wommen hit signifiep impregnacioun . and cesyng of childe berynge / II Vryn of hem pat ben with childe / If pey oon monepe or two or iije florisshe so : peyr vryn shal be ful cleer . and hit shal haue a white ypostasy in pe grounde / And if bey haue foure monepes pe vryn shal be clere and haue a white ypostasi and a picke in pe grounde. Hit was wonte an ymage to appere in be glasen vessel / If pilke vrin be of a womman : hit signifiep be concepcioun to be made . and $\left\{\mathrm{f} .35^{\mathrm{r}}\right\}$ if be ymage of him bat shewip apperep in pe vrin of a seke man : hit signifieb feuers interpolatas . or ellis sekenes of pe lyuer . or drawyng of lengpe of pe sekenes / II Vryn fomy : signifiep ventosite of pe stomake in wommen . or hete from pe nauyl to pe prote and grete dryness and burste / Vryn of a meyde shal be as pe iuse of an orynge appel . where vrin liuida and ful clere declarep pe meyde stedfaste / Vrin trouble in pe whiche sede apperep in pe grounde : hit signifiep pe womman to be with a man $\{$ f. $35 \mathrm{v}\}$ late / Vryn of a womman picke : declarep hir to be corrupte . pe foreseide vrin namely trobul in whiche sede apperep in be grounde of pe vessel / For if suche vrin be in a man $:$ hit declarep him to haue delite with a womman / Vryn of a womman bat is menstruate makep a blody 
vryn / If pis blode be cruddid in a womman : she shal seme with childe til hit be dissolu/eld . as it is shewid in Antidoda .

Here endep pe tretise of pe cercles of vryns with her significacions . and also also pe propirtes $\{$ f. $36 \mathrm{r}\}$ of vryns . and /pel ouer passing excesse of hem and nowe folowep remedy and medysyn for meny of hem bat ben rehersid .

MEdisyn for colour as camelle flesshe / Take pe croppe of sauge and drinke trisandala . and auente pe in pe leggis / Or ellis take pe ynner barke of eldryn tree and grynde hit with ale and clense hit . and drinke hit seuene sponeful at ones and vse hit / al liuida II Plumbea vrina . For pis . take scamonie and do hit in a pere and roste hit and vse hit / Also make a poudre of pe rotis of pyony and persil rotis and be barke of an $\left\{\mathrm{f}_{\mathrm{f}} 36 \mathrm{v}\right\}$ oke and vse hit daily til pu be hole / II Pallida vrina . For pis . take mirabolane . indi . aloes . epatice . cene . sugur . of alle pes a dramme and make a poudre of hem and vse in py potage or in drinke / II Viridis vrina . For pis . take gynger . canel or synamon and sene . and tempere hem with clarified hony . and vse pis at morwe and at euen . II Inopos vrina . For pis . take osemounde . saueyn . and gromel . and boyle hem in white wyne and a litil hony and streine it $\{\mathrm{f} .37 \mathrm{r}\}$ and vse pis drinke erly and late / II Subpallida vrina . For pis . take poudre of grete toonecrasses sede. and vse hem in py potage. If Rubicunda vrina . For pis . take vynegre . mustarde and boyle he $m$ togedir . pen take talwe as moche as a notte and do perto . and ete pis when pe sekenes takep pe I vse also dyacameron and trisandala . II Subcitrina vrina . For pis . take polipodium . anes . alloe . epatice . meddele hem with sugre and make a poudre of pes : and vse in py potage . $\{\mathrm{f} .37 \mathrm{v}\}$ II Subrufa vrina . For bis . take poudre of elenacampana . turmentille medle he $m$ with hony clarified and boyle hem togedre and make perof a confeccioun and use hit day by dai / al subrubia. II Subrubicunda vrina. For pis . / vse pe same medisyn pat longepe to subrufa . as it is nexte afore. II Rubea vrina . For pis . take triacle and boyle hit in pe iuse or water of moleyne and vse hit daily / Also take cassiafistula . tamarindes and triasandali and medle hem togedir and vse pe medisyn daily / \{f. 39r\} II Citrina vrina . For pis . take fyges . licoris . ysope . elenacampana . horehonde . yliche moche . boyle hem in a galoun of water into pe halfe be wastid. and vse pis drinke . at euen and at morwe vij sponful warme. II Subrubea vrina . For pis take water crasses and grynde hem smale and boile hem in wyne . and vse it / II Rufa vrina . For pis take hony and sepe hit til hit be harde and do perto poudir of sene and gynger. and make a plaster of dewete and of wyne / If it be pe flores ley it on pe nauyl. \{f. $39 \mathrm{v}\}$ II 
Kaynos vrina . For pis . take pe bone of an hertis herbe and make perof /al poudir and medle hit with diacameron . and vse pis poudir /in\ by potage or ellis in py drinke. II Lactea vrina . For pis . take pe sede of white popy and bray he $m$ smale and putte he $m$ in letuse water or in pe iuse perof . and medle hem togeder and drinke pat licoure. and vse hit . And anoynte by templis with pis onyment made of henbane . letues - popi and mandrake . and vse hit daily . II Subuiridis vrina . For pis . \{f. 4 or\} lete be seke blede vnder be ancle. or in pe veyne of pe arme . and lete him take a pynte of white wyne and peryn boyle a dramme of alloes and anoper of epatice and drinke of bat a sponeful /at $\backslash$ morowe and anoper at euen . first and last / II Alba vrina . For bis . take saxifrage . gromel . persile . and sage . yliche quantite and boyle hem in gode stale ale . and vse pat drinke on pe morowe and at euen . and also make of pes herbes a poudir and vse hit daily in py potage. II Nigra vrina . For pis . drinke \{f. $40 \mathrm{v}\}$ pe iuse of celidon and of moleine and triacle with wyne . and drinke hit at morwe and at euen . II Glauca vrina . For pis take be iuse of tansy . pe /ribbel worte and boyle hem in /whitel wyne with a litil hony and vse hit And pus pis practif of fisike endep /

II Of euery sekenes thre tymes per be pat muste be obserued and tendrid . pat is to wite . pe begynnyng . pe state and pe ending / If a man sekele of pe axes and be in pe begynnyng \{f. 4Ir\} perof : take for him percelly and fenel . an handful of eche . and sepe hem in a galoun of welle water vntil halfe be almoste wateri . pen take halfe an handful of violettis and putte perto . and let/tle al /pis sepe til hit be incorporate and of oon strengpe . pen streyne hit poroughe a lynen clope and close hit in a close vessel and vse pis drinke fyue daies contynuelli vij spoonful at morwe and at euen as moche luke warme and sanaberis $\therefore$ or sumwhat more of almondis . and a gode handful of violettes $\therefore$ \{f. 4IV\} II For him pat is in pe axes in state. Take sage. meyntis . fopepistil . and lady pistil and sorel yliche moche . and wasshe hem clene and bray hem in a morter and take be iuse of hem and putte in a potel of mylke . pen sette hit ouer pe fire and lete hit sepe til pe mylke may take pe vertu of herbes . pen take a quarte of gode stale ale and put per to. or pre peyntes if hit so nede. and make a possette and vse pe drinke ix daies in al dryness and hetis nyzt and day as ofte as pu wilt . and pu shalt be hole by pe grace of god . \{f. 42r\} II For him pat is trauelid with pe feuers daily or oper. eiper day. Take camylmelle and stampe hit . pen streyne oute pe iuse porough a canues./pen\take pat and sette /itl ouer be fire and lette hit sepe . and alwey scome awey pe fome til hit be clere. and if pu wilt bu may put a quantite of sugur 
perto to make hit pe more liking and when /it is clere . take hit doune and lette hit kele . pen put hit in a close vessel . and vse pe drinke ix daies . vj or vij sponful at ones in pe mornyng and in pe euenyng luke warme. And pe penke camelmyl ouerbitter : pu may take sorel . in be selfe wise . $\{$ f. $42 \mathrm{v}\}$ II For to swage and abate pe malice of pe hote axes / Take mandrake . sorel . syngrene and dauntlyoun yliche moche . and sepe hem in barly mele and vynegre and make of pis a plaster. and ley hit to pe sides of pe seke and to his breste and to pe stomake and to be powes of pe handes and of pe fete and he shal be be hole in short tyme II For him bat pisseb blode / Take wilde sage . saxifrage . percely yliche moche and stampe hem . and put pe iuse in a potel of mylke and lette hit sepe a while . pen streyne hit . and vse be drinke II For dymnes of yen . take cen $\{$ f. $43 \mathrm{r}\}$ tuary and planteyn yliche moche . sepe hem in white wyne and put a litil quantite of piper perto . ben streyne al porough a clene clope and drinke pis medisyn luke warme last when pu goest to by bedde / II For pe coughe / Take elemini fenel sede . longe piper . commyn . and hony as sufficep . Of elemini take .dragme . I . 3 . handful of fenel sede and longe piper ana. dragme vj . of commyn halfe an vnce . and sepe al in a quantite of hony as nedep and vse pe drinke. first and laste / II Electuary for be coughe / Take cynamun . spice . gynger. $\{\mathrm{f} .43 \mathrm{v}\}$ galangal . aneys . longe piper . dra/galgante . ana . dragme semis . pe kernel of pyne clene clensid .dragme . drie figes . dragme ij . and clarified hony as nedep and make electuari and vse hit II Sargarismus . for purgyng of pe hede / Take mustard staffeacre . pelleter . cokil . comfery spiconarde . hony . vinegre . or white wyne menge al togeder and take ij ${ }^{\circ}$ sponful berof and holde in by moupe and rense hit wel perwith . vntil pe fleume descende . pen spet oute pat and take more . so ofte . til pu be esid II For a collerike man bat is dissesid with pe axes pat is caused of \{f. $44 \mathrm{r}$ \} brennyng coler and hete . and also for to ease pe grete dryness pat he hap by pis sekenes / Take borage . violettes . sorel . letwis . endif . soupepistil . stra/ulbery leues . mary goldes . pe tendrons of vynes . dauntlyon . pety morel . malowis . sengryn . persely . langedebef . an handful of eche with pre or iiije stickes of likeris ybrusid . to pouder. and al yput in a galoun of welle water and yconsumed and soden vntil halfe be wastid . pen take hit doune and streyne hit and put hit in a glas . or in a clene erpen pot wel closid . and vse perof at morwe and at euen vj or $\{$ f. $44 \mathrm{v}\}$ vij sponful luke warme and sanab/is $\backslash$ Gargarismus . for pe hede pat is stoppid with reugme and viscous fleume .

\{f. $45 \mathrm{r}$ \} II Ther ben iiij ages in whiche euery humoure hap his duracioun to her likenes . pat is childehode . bachelerhode . manhode . 
and fadirhode / Childehode is fro be begynnyng of birbe into xv zere / bachelerhode . fro xv/zerel vnto xxx . zere / manhode fro xxx zere vnto lx zere / faderhode and olde age fro lx zere vnto pe ende of man is lyfe I II And per ben iiij cesons in pe zere apriped to be foure complexions of men / ver . sommer. haruest and wynter / Ver . is hote and moyst / sommer is hote and drye / haruest is colde and drye / wynter is colde and moist / II Collerike men ben wel in vere . and yuel in sommer / and wel in haruest and in wynter beste at ease / Sanguyne folke ben ywel in ver . and better in sommer and haruest and wynter best at ease / Fleumatike folke ben wel in ver in haruest best and sommer best . and worste in wynter / Malencolious folke ben best in ver and somer. $\{$ f. $45 \mathrm{v}\}$ and worste in haruest . and wynter is not gode / Also per ben iiij wyndes . eest wynde is moyst and hote / soupe wynde is hote and drye / west wynde is colde and moyst / Norpe wynde is colde and drie / And pes be $n$ pe iiij parties of pe worlde . eest . west . soupe and norpe / II Collerike folke ben wel while pe sonne and pe wynde ben eest . west . or norpe / and bey ben yuel. while pe sonne and pe wynde ben soupe / for pat is her quarter / Sanguyne folke ben yuel when be sonne and pe wynde ben eest. for pat is peir quarter. and pey be $n$ wel when pe sonne and be wynde ben soupe. west or norpe / Fleumatike folke ben wel when pe sonne and pe wynde ben eest . soupe or norpe / and bei be $n$ werste when pe sonne and pe wynde be $n$ west /for pat is peir quarter / Malencolious folke be $n$ werst when pe sonne and pe wynde ben norpe $\{$ f. $46 \mathrm{r}\}$ and bey ben wel when sonne and be wynde ben soupe . est . and west / soupe is peir quarter / Nowe folwep pe reignyng of pe iiij $^{e}$ humours in euery man or womman. II Fro be iij of pe clocke after mydde nyzt vntil ix of pe clocke before no/ulne . regnep sanguyne / and from ix of pe clocke afore none vntil pre after no/ulne . regnep colerike / and from pre of /pel clocke after noune vntil ix before mydnyzt . regnep fleumatike / and from ix of pe clocke before mydnyzt vntil iij - after mydnyzt . regnep malencoly / And euery man in pe tyme of pat humoure pat is most regnyng in him / and in pe tyme . pat his humour regnep . is most greued $\therefore$ II For pe morfu . wasshe al by body with water pat stampid garleke is soden yn . and by body is dried and clene . rubbe al pe morfu with garlike and affadile stampid togeder. and vse it so a while and drinke federfoy . eldren fumetory and rede docke rotes made in $\{\mathrm{f} .46 \mathrm{v}\}$ tysane and euery morwe erly drinke a gode draugte . and vse pis medisyn ix daies and pu shalt be clene of pe morfu with yn and wipoute . if pe medisin be wel vsid II For pe iavndise take greynes clowes mases galenga notemygges of eueryche of pes an halfe peny 
worpe / of ysope of hertistonge of celidon ylichemoche and sepe al in pre quartis of white wyne vnto pre pyntes . and vse pis medisyn warme at morwe land $\backslash$ at euen . vj or vij sponeful at ones.

\section{Appendix 1}

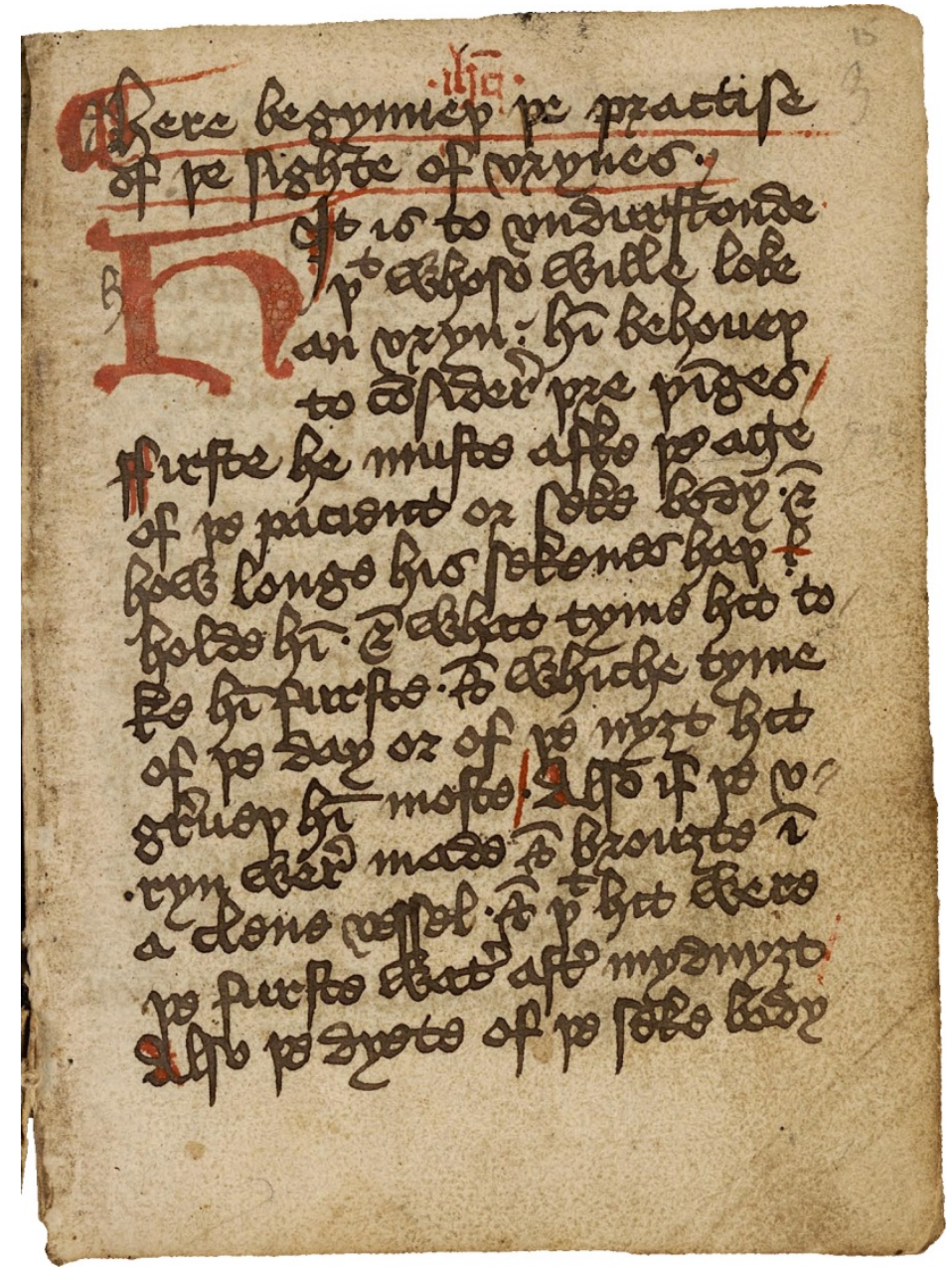

Figure 2. MS Wellcome 537, f. I 5 r.

(c) Wellcome Library, London, as the owner of the manuscript.

\section{References}

Calle Martín, J. \& Miranda García, A. (20II). From the manuscript to the screen: Implementing electronic editions of mediaeval handwritten material. Studia Anglica Posnaniensia 46:3, 3-20. 
Calle Martín, J. \& Miranda García, A. (2012). The Middle English Version of De Viribus Herbarum (GUL MS Hunter 497, ff. Ir-92r). Bern - Berlin Bruxelles - Franfurt - New York - Oxford - Wien: Peter Lang.

Calle Martín, J. (2012). A late middle English version of The Doom of Urines in Oxford, MS Rawlinson C. 8I, ff. 6r-I2v. Analecta Malacitana 35:I-2, $243-273$.

Clemens, R. \& Graham, T. (2007). Introduction to Manuscript Studies. Ithaca and London: Cornell University Press.

Denholm-Young, N. (I954). Handwriting in England and Wales. Cardiff: University of Wales Press.

Derolez, A. (2003). The Palaeography of Gothic Manuscript Books. From the Twelfth to the Early Sixteenth Century. Cambridge: Cambridge University Press.

Hector, L.C. ( I 966). The Handwriting of English Documents. London: Edward Arnold.

Keiser, G.R. (I998). A Manual of the Writings in Middle English I050-I500. Volume X. Works of Science and Information. New Haven, Connecticut: The Connecticut Academy of Arts and Sciences.

Lewis, Robert E., Kurath, H., Sherman, M.K. \& Reidy, J. (eds) (I952-200I). Middle English Dictionary. Ann Arbour: University of Michigan Press. (Electronic dictionary: <http://quod.lib.umich.edu/m/med/lookup.html>).

Moorat, Samuel A.J. (I962). Catalogue of Western Manuscripts on Medicine and Science in the Wellcome Historical Medical Library. Vol. I. Manuscripts Written before I650 AD. London: Publications of the Wellcome Historical Medical Library.

Moreno-Olalla, D. and Miranda-García, A. (2009). An annotated corpus of middle English scientific prose: aims and features. J.E. Díaz Vera and R. Caballero (eds) Textual Healing: Studies in Medieval English Medical, Scientific and Technical Texts ( I23-I 40). Bern-Berlin-Bruxelles-FrankfurtNew York - Oxford - Wien: Peter Lang.

Petti, A.G. (I977). English Literary Hands from Chaucer to Dryden. Cambridge, Mass: Harvard University Press.

Roberts, J. (2005). Guide to Scripts Used in English Writings up to I50o. London: The British Library.

(2005). The Twenty Jordan Series: an illustrated middle English uroscopy text. ANQ: A Quarterly Journal of Short Articles, Notes and Reviews I $8: 3,40-64$. 
Tavormina, M.T. (2009). Practice, theory and authority in a middle English medical text: 'Barton's urines which he treated at Tilney'. Origins of Nephrology 22, $\mathrm{S}_{33}-\mathrm{S}_{4} \mathrm{I}$.

Voigts, L.E. \& Kurtz, P.D. (2000). Scientific and Medical Writings in Old and Middle English. An Electronic Reference. Ann Arbor: Michigan University Press. 